\title{
Bullous varicella in an immunocompetent infant
}

\author{
Siham Mansouri, ${ }^{\oplus}$ Sara Mai, Badr Hassam, Laila Benzekri
}

Dermatology, CHU IBN Sina de Rabat Morocco, Rabat, Morocco

\section{Correspondence to}

Dr Siham Mansouri,

siham-mnsr@hotmail.fr

Accepted 13 March 2019

\section{DESCRIPTION}

A Moroccan 6-month-old boy with no known medical problems or previous drug intake, was admitted to the paediatric department with a 2week history of high-grade fever with subsequent eruption of multiple bullous lesions on the entire body, unsuccessfully treated with amoxicillin and clavulanic acid for 10 days. The lesions started as vesicules on the forehead which spread to involve the entire body in a span of 3 days. There was no history of varicella infection or vaccination but he had been in direct contact with his sister, who had chickenpox. Physical examination revealed multiple tense bullous lesions ranging in size from 6 to $40 \mathrm{~mm}$ in diameter scattered mostly over the trunk, neck and face, with multiple erosions in the oral cavity (figures 1 and 2). Laboratory investigation revealed an absolute monocytosis and increased inflammatory markers. Other blood parameters were within normal range. Both blood culture and sensitivity (C\&S), as well as swab C\&S taken from the ruptured bullous had negative yield. Tzanck's smear was positive for multinucleated giant cells. Varicella zoster virus (VZV) IgM antibody titres were raised (28.72 NovaTec-Units (NTU)). The diagnosis of bullous varicella was performed based on family history of chickenpox, clinical and biological findings. The patient was treated with acyclovir $10 \mathrm{mg} / \mathrm{kg}$ body weight 8 hourly intravenously for

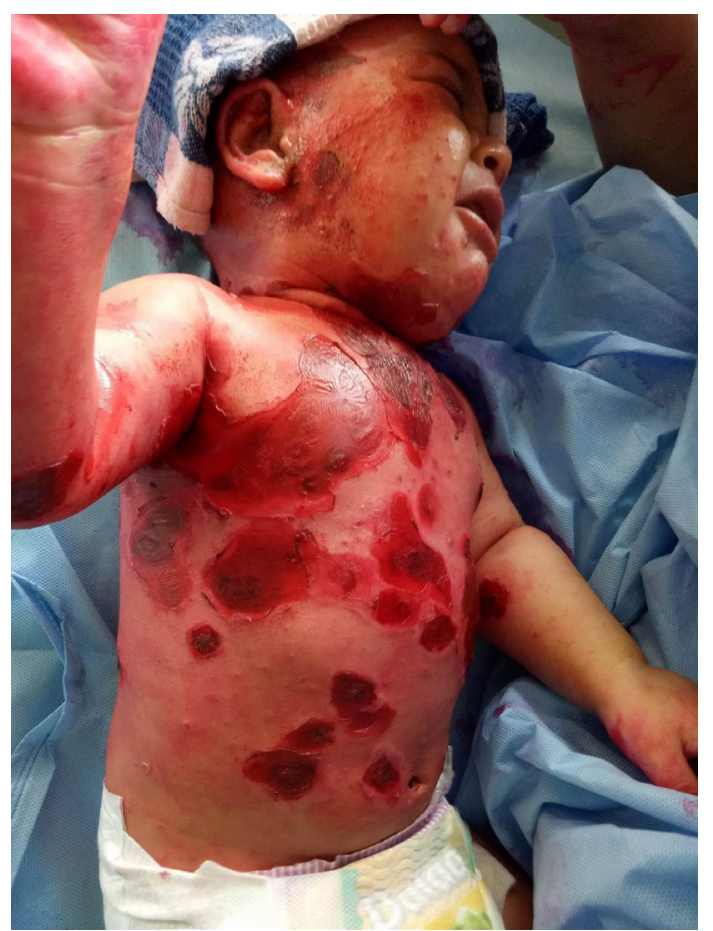

Figure 1 Bullous varicella.

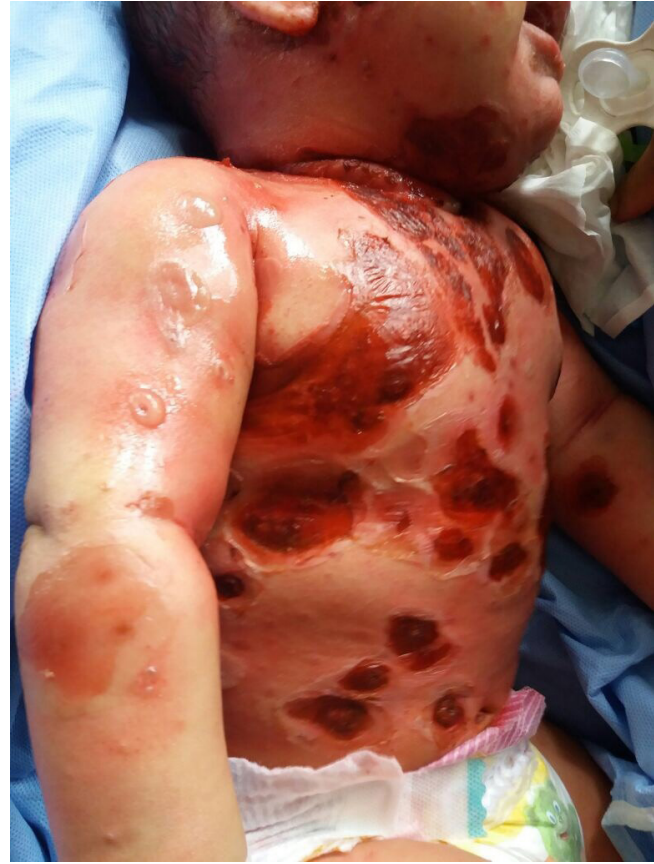

Figure 2 Large bullae and typical chickenpox lesion seen on the skin.

10 days with complete healing within 2 weeks with slightly atrophic hypopigmented macules.

Chickenpox is a highly contagious airborne disease caused by the VZV. Most often benign and self-limiting, chickenpox is one of the most common childhood diseases. However, varicella continue to cause significant morbidity and even mortality. Complications include bacterial surinfection, pneumonia, meningitis, encephalitis, cerebellar ataxia and pain syndromes. ${ }^{12}$ Chickenpox in infants may lead to complications when it occurs in-between the loss of the maternal antibodies and the recommended age for vaccination. Atypical clinical complications of varicella have been described and can be a diagnostic and therapeutic challenge. The most frequent cutaneous complication of varicella is bacterial surinfection, caused often by Staphylococcus aureus or Streptococcus pyogenes, which can accentuate the scarring and rarely lead to staphylococcal and streptococcal toxic shock syndromes. ${ }^{2} \mathrm{~A}$ severe form of cellulitis and necrotising soft tissue infection has been reported following varicella which are caused by strains of group $\mathrm{A} \beta$-haemolytic streptococci. Also, some authors reported a possible association with the use of non-steroidal anti-inflammatory drugs. ${ }^{2}$ These severe conditions need an early and agressive therapy: surgical debridement for the necrotising fasciitis, appropriate antibiotic therapy and intensive supportive care. However, these complications can be prevented by 
keeping a good cutaneous hygiene, trimming patient's fingernails, prescribing antihismines for the pruritus, avoiding nonsteroidal anti-inflammatory drugs and using alternative drugs for relief of fever and pain in patients with varicella. Other cutaneous complications of varicella include haemorrhagic varicella and purpura fulminans. ${ }^{2}$

Bullous onset of chickenpox as seen in our case is an extremely rare manifestation which is more commonly seen in immunocompromised children contrarely to our patient who was immunocompetent. ${ }^{2-6}$ The exact mechanisms by which large bullae are formed are not clear, some synergistic effect between the infectious agents must occur. It has been suggested that bullous lesions result from secondary bacterial infection most commonly Staphylococcus. ${ }^{6}$ It is uncertain which of the two agents has the greater contribution to the formation of bullae.

The diagnosis is difficult to make according to the clinical presentation. Histological confirmation is rarely necessary, but a blood test is available to detect VZV antibodies. Modern

Learning points

- Raise awareness of severe complications which may take place following varicella infection, in both immunocompetent and immunocompromised individuals.

- Highlight bullous varicella as one of the possible cutaneous complications of Varicella zoster virus infection which presentation might mimic bacterial infection and represent a diagnostic and therapeutic challenge.

- Adequate prophylaxis, vaccination coverage and early management contribute to avoiding complications in the high-risk population. techniques including PCR have provided new insight into this problem, strongly supporting VZV involvement in the development of bullae. Vaccination coverage and adequate prophylaxis contribute to avoiding complications in the high-risk population. ${ }^{7}$ Early management of patients presenting with chickenpox is crucial. Effective treatment with acyclovir, combined with hygiene precautions, has proved effective in reducing virus transmission and in preventing the emergence of postexposure cases.

Contributors SM: the doctor who took care of the patient and wrote the article. SM: the doctor who collaborated in the care of the patient and the design of the article. LB: The professor who is responsible for the consultations and therapeutic decisions of the patient and contributed in the design and execution of the paper. BH: The Dermatology Department Head who is responsible for all professional and scientific activities.

Funding The authors have not declared a specific grant for this research from any funding agency in the public, commercial or not-for-profit sectors.

Competing interests None declared.

Patient consent for publication Not required.

Provenance and peer review Not commissioned; externally peer reviewed.

\section{REFERENCES}

1 Gershon AA. Is chickenpox so bad, what do we know about immunity to varicella zoster virus, and what does it tell us about the future?. J Infect 2017;74(Suppl1):S27 - S33.

2 Gnann JW. Varicella-zoster virus: atypical presentations and unusual complications. J Infect Dis 2002;186(Suppl1):S91-S98.

3 Peyramond D, Bertrand JL, Bertoye A. [Bullous varicella. Association of varicella and a childhood scalded-skin syndrome]. Arch Fr Pediatr 1979;36:922-5.

4 Sathynarayana BD. Varicella bullosa. Indian J Dermatol Venereol Leprol 2003;69:56-7.

5 Sulik A, Szkoda MT, Oldak E. Bullous varicella in a 5-month-old infant. Clin Exp Dermatol 2008;33:102-3.

6 Suvirya S, Jain A, Agrawal A, et al. Monomorphic bullous hemorrhagic varicella in a patient on methotrexate. Indian Journal of Paediatric Dermatology 2018;19:59.

7 Lo Presti C, Curti C, Montana M, et al. Chickenpox: An update. Med Mal Infect 2019;49:1-8.

Copyright 2019 BMJ Publishing Group. All rights reserved. For permission to reuse any of this content visit

https://www.bmj.com/company/products-services/rights-and-licensing/permissions/

BMJ Case Report Fellows may re-use this article for personal use and teaching without any further permission.

Become a Fellow of BMJ Case Reports today and you can:

- Submit as many cases as you like

- Enjoy fast sympathetic peer review and rapid publication of accepted articles

- Access all the published articles

- Re-use any of the published material for personal use and teaching without further permission

For information on Institutional Fellowships contact consortiasales@bmjgroup.com

Visit casereports.bmj.com for more articles like this and to become a Fellow 